\title{
Unobtrusive measurement of psychological constructs in organizational research
}

Organizational Psychology Review 20I4, Vol. 4(2) I48-174

(C) The Author(s) 2013

Reprints and permission: sagepub.co.uk/journalsPermissions.nav DOI: I0.I I77/204|3866/35056/3 opr.sagepub.com

\section{Aaron D. Hill}

Oklahoma State University, USA

Margaret A. White

Oklahoma State University, USA

\section{J. Craig Wallace}

Oklahoma State University, USA

\begin{abstract}
Measurement in organizational psychology is dominated by the use of approaches that require the cooperation of a respondent-namely, questionnaires and interviews. The goal of this article is to increase and improve the use of unobtrusive measures as a supplemental means to assess psychological constructs in organizational research. Specifically, we first illustrate the merit and necessity of utilizing unobtrusive measures. Next, we review the literature employing unobtrusive measures to assess psychological constructs and then discuss threats to validity associated with these approaches. Finally, we offer recommendations to enhance the effectiveness of unobtrusive measures in future research.
\end{abstract}

\section{Keywords}

Cognition/perception, personality and individual difference, statistics/methods

This survey directs attention to social science research data not obtained by interview or questionnaire. Some may think this exclusion does not leave much. It does. Many innovations in research method are to be found scattered throughout the social science literature. Their use, however, is unsystematic, their importance understated. Our review of this material is intended to broaden the social scientist's currently narrow range of utilized method-

Paper received 28 January 2013; revised version accepted 25 August 2013.

Corresponding author:

Aaron D. Hill, Spears School of Business, Oklahoma State University, 2 I I Business Building, Stillwater, OK 74078, USA. Email: aaron.hill@okstate.edu 
ologies and to encourage creative and opportunistic exploitation of unique measurement possibilities. Today, the dominant mass of social science research is based upon interviews and questionnaires. We lament this overdependence upon a single, fallible method.

Opening lines of the Webb, Campbell, Schwartz, and Sechrest 1966 book, Unobtrusive Measures

Nearly 50 years have passed since Webb, Campbell, Schwartz, and Sechrest's (1966) call for researchers to supplement interviews and questionnaires with unobtrusive measures, which they define as "measures that do not require the cooperation of a respondent and that do not themselves contaminate the response" (p. 2). The central premise of Webb and colleagues' work, summarized in the previous introductory excerpt, holds true in organizational psychology research today: measurement is dominated by approaches that require cooperation of a respondent (e.g., a focal respondent's self-report or an alternate respondent who knows the focal individual; Morgeson et al., 2007; Oh, Wang, \& Mount, 2011; Ones, Dilchert, Viswesvaran, \& Judge, 2007; Zimmerman, Triana, \& Barrick, 2010) and while examples of alternative approaches are scattered throughout the literature (e.g., Chatterjee \& Hambrick, 2007, 2011; Chen \& Meindl, 1991; McClelland, Liang, \& Barker, 2010; Peterson, Smith, Martorana, \& Owens, 2003), the methodological rigor of some of these inquiries has been questioned (e.g., Hiller \& Hambrick, 2005; Hollenbeck, DeRue, \& Mannor, 2006; Lawrence, 1997; Nadkarni \& Herrmann, 2010; Pitcher, Chreim, \& Kisfalvi, 2000; Priem, Lyon, \& Dess, 1999). Thus, our purpose mirrors that of Webb and colleagues': to provide a systematic review of unobtrusive measurement that calls attention to the value of these measures for organizational researchers and, in light of concerns with the methodological rigor of these approaches as well as the lack of a resource that addresses them, offer a guide for using unobtrusive approaches to generate valid measures of psychological constructs.

Our review of unobtrusive measurement of psychological constructs addresses two interrelated issues facing scholars. First, all methods have limitations, and thus overreliance on any one approach limits not only what knowledge we can gain but also the strength of the knowledge (Campbell \& Fiske, 1959). As Webb et al. (1966, p. 173) note, "so long as one has only a single class of data collection ... one has inadequate knowledge." Thus, to maximize what knowledge we can gain, it is important for researchers to have an understanding of the full complement of techniques at their disposal. Second, Webb and Weick (1979) argue that while scholars acknowledge the need to utilize multiple approaches, so long as they lack exposure to unobtrusive approaches they may continue to employ the approaches with which they are familiar and that they see as dominant in the field. Relatedly, without a source to turn to for guidance, scholars may employ unobtrusive measures in a way that does not leverage their benefits. Thus, our review serves not only to highlight the merit and necessity of utilizing unobtrusive measures to assess psychological constructs as an alternative to the dominant approach, but also offers an organizing framework of the various unobtrusive measures that exposes scholars to a variety of alternatives. In doing so, we discuss specific threats to validity related to each of the unobtrusive measurement approaches identified and recommend practices that can enhance their effectiveness in future research with a focus on overcoming extant threats.

Prior to moving forward, we wish to highlight three points from the Webb et al. (1966) exposition. First, we wish to emphasize that the intent of our review is not to make a call for replacing questionnaires and interviews, but rather to call attention to the merit of utilizing unobtrusive measures as a supplemental approach. For example, Insch, Moore, and Murphy (1997) note 
that studying cognitive constructs in leaders unobtrusively by examining traces of oral and written communication in sources such as letters to shareholders and inaugural addresses avoids problems associated with interacting directly with the leaders to obtain measures. Similarly, Chatterjee and Hambrick (2007, p. 362) note that using evidence that executives leave behind in their physical environment can "eliminate problems of reactivity, demand characteristics, and researchers' expectations that can weaken other methods."

Second, Webb and colleagues highlight that unobtrusive information sources provide insight on individuals' values, cognitions, and mental functioning across a number of settings. As such, they implore researchers to creatively exploit the opportunities that these information sources provide for measurement. In line with their view, we are hesitant to narrow the scope of our review from the admittedly broad domain of "psychological constructs in organizational research" for fear of providing proverbial blinders that constrict researchers' vision with respect to how they may utilize unobtrusive measurement. Thus, our review draws from examples of various psychological constructs (e.g., values, cognition, personality) in hopes of offering exposure to, and spurring inventiveness with respect to the use of, unobtrusive measurement across a number of research streams within organizational psychology.

Third, like Webb et al. (1966), we acknowledge that the use of certain information sources to base psychological assessments may be questionable on ethical grounds and that researchers are unlikely to view these questions with unanimity. Further, technological and societal changes over time alter what sources of information researchers can access and the ease of doing so, in turn giving rise to new ethical considerations. Nonetheless, we share Webb and colleagues' (p. vii) view that "ethical criteria can be met without impinging on important interests of the research subjects" when using unobtrusive measurement. Although a thorough discussion of the ethics of information use is beyond the scope of our review, we wish to emphasize that information used to unobtrusively measure psychological constructs should be used in a way that protects subjects. Thus, as with any other measurement approach, readers should consider the principles of the Belmont Report (The National Commission for the Protection of Human Subjects of Biomedical and Behavioral Research, 1979; i.e., respect for persons, beneficence, and justice) and adhere to both the American Psychological Association's Ethical Principles of Psychologists and Code of Conduct (2010) as well as institutional review board policies when gathering data.

\section{Merit and necessity of unobtrusive measures for studying psychological constructs}

All measurement approaches have strengths and limitations that researchers must consider. Because of the difficulty in measuring psychological constructs and the limitations of any single measurement approach, scholars have long noted the benefits associated with utilizing multiple approaches to assess a construct (e.g., D. T. Campbell \& Fiske, 1959; Edmondson \& McManus, 2007). The benefit of using multiple approaches is that each approach has strengths and overcomes certain limitations of other approaches. If done well, the net result is an enhanced ability to build knowledge about the focal construct when multiple approaches are used. Our focus is on the approach of using unobtrusive measures, defined as "measures that do not require the cooperation of a respondent and that do not themselves contaminate the response" (Webb et al., 1966, p. 2). That is, unobtrusive measures are those that permit researchers to gain information about subjects without the researcher, the subject, or others who know the subject intruding into the research context (Trochim \& Donnelly, 2006). Like all measures, unobtrusive measures 
have strengths that overcome certain limitations of other approaches.

A first benefit of unobtrusive measures is that they offer a nonreactive measurement because the subjects do not realize they are being measured (Webb et al., 1966; Webb \& Weick, 1979). That is, the subjects are not able to change their reactions owing to being measured, as may happen in other approaches. For example, scholars find that even willing participants may not be amenable to accurate measurement of certain psychological constructs because, among other concerns, subjects: (a) expend considerable effort managing the impressions that other people have of them (Day, Schleicher, Unckless, \& Hiller, 2002), (b) are prone to alter responses to sensitive inquires (Seidel \& Westphal, 2004; Tourangeau, Rips, \& Rasinki, 2000), and (c) often lack trust regarding the use of their responses and thus alter them (Carter, Dala, Lake, Lin, \& Zickar, 2011). Collectively, these concerns threaten validity of measurement approaches in which the individuals realize they are being measured (e.g., Morgeson et al., 2007). Worse, the aforementioned problems are often exacerbated when individuals are not willing participants (Anseel, Lievens, Schollaert, \& Bhoragwicka, 2010; Becker \& Meyers, 1974; Cycyota \& Harrison, 2002, 2006; Dundon \& Ryan, 2010), and organizational researchers are often faced with attempting to assess the psychological constructs of individuals who are less than enthused about participating. Further, individuals' reluctance to participate in measurement may be exacerbated in certain business climates as increasing scrutiny of their behaviors may cause them to be even more skeptical about such inquiries (Anseel et al., 2010; Cycyota \& Harrison, 2006; Hirsch \& Pozner, 2005). In contrast, if the individuals do not know they are being studied — as is the case with unobtrusive measures - it is not possible for them to withhold or alter responses. As a result, nonresponse and socially desirability biases associated with the focal individuals are lessened (Kluemper \& Rosen, 2009; Kluemper, Rosen, \& Mossholder, 2012).
A second strength of unobtrusive measures is that they allow researchers to use a variety of information as a basis for measuring psychological constructs. Given the vast amount of information available in various forms, the use of such information as a basis for unobtrusive measurement can increase the size and diversity of the samples available to investigators. For example, Internet websites, particularly those used for social networking, serve as sources of information about current and prospective employees (e.g., Davison, Maraist, \& Bing, 2011; Davison, Maraist, Hamilton, \& Bing, 2012; Kluemper \& Rosen, 2009; Kluemper et al., 2012). As such, these sources offer potential for a broader assessment of candidates. Not only can employers ascertain what candidates are like when they are not trying to manage impressions during an interview, but using websites also allows organizations to assess a larger number of candidates than is possible with time-consuming face-to-face interviews. Simply put, information on the Internet serves as an alternative means to assess individuals and allows for assessing a larger number of individuals in less time than in person. These same benefits may be afforded to scholars given both the increasing access to such information and advances in technology to capture it (see also, Back et al., 2010; Cohn, Mehl, \& Pennebaker, 2004; Mehl \& Pennebaker, 2003b).

Third, the increasing availability of unobtrusive information sources allows researchers to expand inquiries to alternative samples and periods. The former issue is beneficial in assessing generalizability and external validity (D. T. Campbell \& Fiske, 1959; Edmondson \& McManus, 2007). That is, since both a greater amount and a wider variety of data is availablerather than limiting the sample to a single context because of various constraints associated with time and cost of conducting such inquiries - scholars can access various sources in a timely and cost-efficient manner. Further, this approach allows scholars to assess whether findings hold across different contexts. The latter 
issue, that archiving of data enables researchers to investigate phenomena longitudinally by accessing information over time, is beneficial in that longitudinal investigations may not be practical with other measurement approaches due to the time- and cost-prohibitive nature of conducting such inquires as well as the difficulties researchers face with subject mortality in longitudinal studies (Cook \& Campbell, 1979). Not only are such archival sources becoming more widely available with advances in technology (Zickar \& Carter, 2010), but the increasing reliance on technology in the workplace also serves to create an information trail that may be fruitful for researchers. As this information is stored over time, researchers may be able to use the information for longitudinal research. Such information may be particularly prevalent in public companies and governmental agencies that are required to make certain information available (e.g., certain personal files, memos, e-mails, text messages on company phones). Unobtrusive measures serve as means to use this information to assess individuals' psychological constructs and subsequently link to a variety of outcomes.

In sum, unobtrusive measures have a number of merits: they offer nonreactive measurement and hence avoid concerns with reluctant or compromised respondents, they allow researchers to utilize vast sources of available information, and they allow extension to alternative samples and periods. Given the issues that unobtrusive measures address, it is perhaps not surprising that these approaches have become the norm in research on executive psychology (Carpenter, Geletkanycz, \& Sanders, 2004; Finkelstein, Hambrick, \& Cannella, 2009). That is, since executives are reluctant to participate in scholarly interviews, allow scholars to directly observe their actions, or respond to questionnaires (e.g., Cycyota \& Harrison, 2002, 2006; Hambrick \& Mason, 1984; Mintzberg, 1973; Norburn, 1989; Pettigrew, 1992) unobtrusive measures are particularly prevalent as means to overcome these limitations. As we highlight unobtrusive measures employed in the literature, we draw heavily on examples from the context of executives because unobtrusive measures are more widely applied in that research stream than in investigations of individuals at lower levels of the firm. Further, a number of important areas remain understudied because researchers face difficulties with access to and/or reluctance of respondents (Dundon \& Ryan, 2010; Kriauciunas, Parmigiani, \& Rivera-Santos, 2011; Peterson, Smith, \& Martorana, 2006) as well as with measuring certain constructs via interview and survey (Day et al., 2002; Morgeson et al., 2007; Seidel \& Westphal, 2004; Tourangeau et al., 2000). Although we rely heavily on examples from the executive literature, we note several examples from investigations at lower levels of the organization, where unobtrusive measures are increasingly utilized in investigations of psychological constructs (e.g., Kluemper \& Rosen, 2009; Kluemper et al., 2012).

Unobtrusive measures can be valuable or even necessary in building knowledge in a number of research streams to overcome various difficulties. For example, Bolino, Kacmar, Turnley, \& Gilstrap (2008, p. 1089) note that despite a wealth of research on impression management tactics, research on "exemplification, supplication, and intimidation have been addressed far less frequently" while "excuses, justifications, self-handicapping, and apologies have generally been ignored." It may be that the less frequent research of these impression management tactics is because it is harder to get subjects to respond to inquiries about their use of such tactics. Unobtrusive measures that use alternative information sources may be beneficial in gaining insight in these hard-to-access areas of impression management. Similarly, unobtrusive measures may be valuable to other research streams where problems with questionnaire and interview responses make measurement difficult, including unethical behaviors like fraud and corruption (Ashforth, Gioia, Robinson, \& Trevino, 2008; DeCelles, DeRue, Margolis, \& Ceranic, 2012; Zahra, Priem, \& 
Rasheed, 2005), psychological responses to traumatic incidents like 9/11 (Cohn et al., 2004; Mehl \& Pennebaker, 2003a), ostracism (D. L. Ferris, Brown, Berry, \& Lian, 2008), and views of the opposite gender (Vecchio, 2002). Investigations of constructs where evolution over time is an important element such as reputation $(\mathrm{G}$. R. Ferris, Blass, Douglas, Kolodinsky, \& Treadway, 2003; Zinko, Ferris, Blass, \& Laird, 2007) and popularity (Scott, 2013) seem particularly apt for unobtrusive measurement as well given subject mortality constraints facing other methods.

\section{An overview of unobtrusive measures in extant research}

In this section, we focus on summarizing the logic connecting the information source to the subsequent measure and on providing examples of each source. As such, we withhold critique of the measures until later in the manuscript. While other organizing structures are possible, we follow the logic of using the information source as a classification structure (Combey, 1980; Galtving, 1967). Thus, we distinguish the use of two information sources of unobtrusive measures-language and behaviors. Languagebased measures include a broad group of techniques employed to assess constructs using written or spoken words while behavior-based measures include a broad grouping of techniques employed to assess constructs using information on how individuals behave (i.e., what they have done or how they have acted).

\section{Language-based measures}

Research that utilizes language as a measure of psychological constructs is based upon the belief that peoples' linguistic style typically reflects their underlying psychological characteristics (for a recent review, see Pennebaker, Mehl, \& Niederhoffer, 2003). That is, because written and spoken words are "a form of expressive behavior" that reflect the psychological constructs of an individual that are "the most dominant and consistent" (Chatterjee \& Hambrick, 2007, p. 364), analyzing language use may provide insight into these constructs. Similarly, using the written and spoken words drawn from other sources in reference to the individual may provide similar insight. With recent advances in technology, analyzing sources such as text messages, e-mails, and information posted online in the form of blogs, microblogs, and video blogs ("vlogs") is increasingly becoming viable (Davison et al., 2011; Davison et al., 2012; Kluemper \& Rosen, 2009; Kluemper et al., 2012). Such sources of information may be of value for generating language-based measures of individuals' psychological constructs as well.

After obtaining a sample of language usage, language-based measures are typically developed through content analytic techniques (Duriau, Reger, \& Pfarrer, 2007; Pennebaker et al., 2003). Although technological advances may increase the ease of conducting computeraided content analyses (Short, Broberg, Cogliser, \& Brigham, 2010; Short \& Palmer, 2008), several scholars employ human coders as well to develop measures (e.g., Hambrick \& Abrahamson, 1995; House, Spangler, \& Woycke, 1991; Peterson et al., 2003). Scholars also utilize both methods in efforts to cross-validate measures prior to use in subsequent analyses. Regardless of whether using computer-aided analysis or human reviewers to code the information, each approach is amenable to reliability and validity estimations to establish whether the use of the measure is warranted.

Three sources are utilized to develop language-based methods (see Table 1.) First, scholars use words written or spoken by a focal individual to assess his or her underlying psychological constructs. Much like using information from a traditional interview setting of the focal respondent, utilizing an individuals' words is beneficial in that this approach provides a direct assessment of the population of interest (Dobbins, Lane, \& Steiner, 1986). For example, 
Table I. Language-based methodologies employed to assess constructs.

\begin{tabular}{|c|c|c|}
\hline Theoretical logic & Information sources & Examples \\
\hline $\begin{array}{l}\text { One's linguistic style typically reflects } \\
\text { his or her actual psychological } \\
\text { constructs }\end{array}$ & $\begin{array}{l}\text { I. Words written or } \\
\text { spoken directly by an } \\
\text { individual }\end{array}$ & $\begin{array}{l}\text { Transcriptions of spoken } \\
\text { statements (Chatterjee \& } \\
\text { Hambrick, 2007; Golden-Biddle \& } \\
\text { Rao, I997; Rovenpor, 1993; } \\
\text { Winter, I987b) } \\
\text { - Written samples (House et al., } \\
\text { 1991; Pennebaker \& King, I999; } \\
\text { Vazire \& Gosling, 2004) } \\
\text { - Words used in social interactions } \\
\text { (Gibson et al., 1993; Ickes et al., } \\
\text { 1986) }\end{array}$ \\
\hline & $\begin{array}{l}\text { 2. Language accredited to } \\
\text { the individual but at least } \\
\text { partially attributable to } \\
\text { others }\end{array}$ & $\begin{array}{l}\text { - Letters to shareholders } \\
\text { (Bettman \& Weitz, I983; } \\
\text { D'Aveni \& MacMillan, 1990; } \\
\text { McClelland et al., 2010) } \\
\text { - Proxy statements (Nadkarni \& } \\
\text { Narayanan, 2007a; Short \& } \\
\text { Palmer, 2008) }\end{array}$ \\
\hline $\begin{array}{l}\text { Statements made by others about the } \\
\text { individual provide insight into the } \\
\text { individual's psychological } \\
\text { constructs as viewed by those who } \\
\text { interact with him or her }\end{array}$ & $\begin{array}{l}\text { I. Comments made in } \\
\text { reference to the } \\
\text { individual by other } \\
\text { individuals }\end{array}$ & $\begin{array}{l}\text { - Colleagues (House et al., I99I; } \\
\text { Simonton, I986, I988) } \\
\text { - Scholarly observers (Peterson } \\
\text { et al., 2003) } \\
\text { - Media reports (Brown \& Sarma, } \\
\text { 2007; Hayward \& Hambrick, } \\
\text { 1997; Jin \& Kothari, 2008) } \\
\text { - Legal documents (Alison et al., } \\
\text { 200I; Langton \& Piquero, 2007; } \\
\text { Wheeler et al., 1982) }\end{array}$ \\
\hline
\end{tabular}

a variety of sources are used to develop measures based on the language used directly by an individual but not collected by a scholar who was interviewing the subject, including public speeches (Rovenpor, 1993; Winter, 1987b), meeting minutes (Golden-Biddle \& Rao, 1997), and words used in unstructured social interactions (Gibson, Fiedler, \& Barrett, 1993; Ickes, Reidhead, \& Patterson, 1986; Mehl, Gosling, \& Pennebaker, 2006) as well as analysis of written statements in diaries and autobiographical statements (Brundin \& Nordqvist, 2008; House et al., 1991; Pennebaker \& King, 1999; Vazire \& Gosling, 2004; Winter, 2005). Similarly, websites such as YouTube that contain videos of individuals may serve as a source of information from which to assess the psychological constructs of the individual, as may personal statements available through sources such as Facebook, LinkedIn, Monster.com, or even e-mails.

Second, language accredited to a focal individual that is at least partially attributable to other individuals serves as a source from which to assess the psychological constructs of the focal individual. For instance, letters to shareholders and proxy statements (D'Aveni \& MacMillan, 1990; Nadkarni \& Narayanan, 2007a; Short \& Palmer, 2008), which are typically crafted either by public relations staffers or in a joint effort of individuals (Rovenpor, 1993; Salancik \& Meindl, 1984), are often attributed to the CEO and utilized to assess his or her psychological constructs. Similarly, such sources 
have also been used to assess the psychological constructs of the broader group of executives on the top management team. As McClelland et al. (2010, p. 1261) note "strong arguments" can be made in favor of such attributions since executives are legally responsible for such communications; it can therefore be assumed that they review and have ultimate say about their content. Further, the fact that "considerable research has been published in the past" using this information "attests to their reliability as sources" (2010, p. 1261). Examples of measurement based upon language accedited to a focal individual that is at least partially attributable to other individuals have been primarily confined to research at the level of top management; still, documents produced at least partially in collaboration with other individuals occur at many levels of the organizational hierarchy, and these documents may provide insight into the author(s) psychological constructs. Further, the logic that McClelland and colleagues apply to executives - that the subject's or subjects' responsibility for the content of the communication indicates the communication is a reliable source of insight on certain psychological constructs - would be similar across levels of the organization and perhaps even hold greater validity outside of the executive setting. That is, the fact that an individual or group of individuals is responsible for producing the content provides a link between the subject(s) and the subsequent use of the content to measure psychological constructs. Further, the connection between the subject(s) and content may be stronger at lower levels of the organizational hierarchy given that these individuals may be less likely to be able to rely on ghost writers to produce the content.

Third, scholars use statements made by others about an individual to gain "direct insight into the type of person" the individual is as assessed by those who interact with him or her (Malmendier $\&$ Tate, 2008, p. 38). For example, information may be drawn from statements made by colleagues (House et al., 1991; Simonton, 1986; Stiles, 2001), media reports (Brown \& Sarma,
2007; Hayward \& Hambrick, 1997; Jin \& Kothari, 2008), biographers (Simonton, 1988; Winter, 2005), and even customers (Mount, Barrick, \& Strauss, 1994). Scholars have even utilized information as diverse as police reports (Alison, Snook, \& Stein, 2001) and presentencing investigative reports provided to judges (Langton \& Piquero, 2007; Wheeler, Weisburd, \& Bode, 1982) to gain insight into the psychological constructs of individuals convicted of crimes. Other potential avenues exist, including using websites, to ascertain statements that individuals make about a focal other as well as analyzing supervisors' comments contained in performance appraisals and exchanges in company e-mails that reference other individuals.

\section{Behavior-based measures}

The second category of unobtrusive measures utilizes behaviors to assess underlying psychological constructs. Behavior-based measures build upon behavioral consistency theories, which argue that how individuals behave is both consistent across situations and is indicative of underlying psychological constructs that drive the behaviors. Thus, scholars who base measures upon individual's behaviors argue that the behaviors provide insight into the underlying psychological constructs that drove the individual to act in such a manner (Allport, 1937; Brunswik, 1956; Funder \& Colvin, 1991; Goffman, 1959; Hambrick \& Mason, 1984). For example, given the riskiness associated with flying, the behavior of pursuing a pilot's license may provide insight into the individual's risk tolerance (Cain \& McKeon, 2012). Similarly, behaviors such as stock-option exercises (T. C. Campbell, Gallmeyer, Johnson, Rutherford, \& Stanley, 2011; Malmendier \& Tate, 2005, 2008), personal investment strategies, entrepreneurial activities, as well as smoking and drinking alcohol (Barsky, Juster, Kimball, \& Shapiro, 1997; Cronqvist, Makhiga, \& Yonker, 2012) have been used to measure various psychological constructs of focal individuals as have prior experiences such 
Table 2. Behavior-based measures employed to assess constructs.

\begin{tabular}{|c|c|c|}
\hline Theoretical logic & Information sources & Examples \\
\hline $\begin{array}{l}\text { Analyzing behaviors provides insight } \\
\text { into the underlying psychological } \\
\text { constructs that drove the individual } \\
\text { to act }\end{array}$ & $\begin{array}{l}\text { - Behaviors of an } \\
\text { individual }\end{array}$ & $\begin{array}{l}\text { - Investment decisions (Malmendier \& } \\
\text { Tate, 2005, 2008; T. C. Campbell et al., } \\
\text { 20II) } \\
\text { - War entry/avoidance (House et al., } \\
\text { I99I; Winter, I980) } \\
\text { - Arrangment of personal spaces } \\
\text { (Gosling et al., 2002; Vazire \& Gosling, } \\
\text { 2004) } \\
\text { - Personal practices (Aaker et al., 200I; } \\
\text { Cain \& McKeon, 20I2) }\end{array}$ \\
\hline $\begin{array}{l}\text { Analyzing behaviors of a collective (e.g., } \\
\text { group, organization) provides insight } \\
\text { into the psychological constructs of } \\
\text { individuals in the collective because: } \\
\text { I. People inject a great deal of } \\
\text { themselves into the collective } \\
\text { 2. Behaviors of a collective are in } \\
\text { large part determined by } \\
\text { individuals }\end{array}$ & $\begin{array}{l}\text { - Behaviors of a } \\
\text { collective } \\
\text { attributed to an } \\
\text { individual }\end{array}$ & $\begin{array}{l}\text { - Organizational compensation practices } \\
\text { (Chatterjee \& Hambrick, 2007, 20I I; } \\
\text { Hayward \& Hambrick, I997) } \\
\text { - Use of official titles (Finkelstein, 1992; } \\
\text { Harrison et al., I988) } \\
\text { - Layout of organizational documents } \\
\text { (Chatterjee \& Hambrick, 2007, 20II) } \\
\text { - Performance (Hayward \& Hambrick, } \\
\text { 1997) }\end{array}$ \\
\hline
\end{tabular}

as having a background in entrepreneurial finance, an advanced educational degree, or attending Ivy League Universities (Dalziel, Gentry, \& Bowerman, 2011). Other examples include employing information drawn from GPS software and employment records, which provide insight on how individuals behave, such as in patterns of movement (GPS) or prior actions in the workplace (employment records).

After obtaining a sample of behaviors, measures are created in various ways such as by counting instances, using relative ratio or frequency of behaviors, and employing indexes of behaviors. Final measures are based upon both single-item measures as well as the use of multiple measures summated in the same fashion as is common in creating a multi-item questionnaire. Although a thorough discussion of psychometric practices is outside the scope of this article, we address this issue in more detail in the Recommendations section.

Examples of behaviors utilized in extant research to unobtrusively measure individuals' psychological constructs are highlighted in Table
2. As the table illustrates, a variety of behaviors are used to assess individuals' psychological constructs. For instance, both Winter (1980) and House et al. (1991) analyze the war entry and avoidance behaviors of U.S. presidents, while others utilize sources as diverse as how individuals lay out their personal web pages (Vazire \& Gosling, 2004) or bedroom and office spaces (Gosling, Ko, Mannarelli, \& Morris, 2002), and the length of biographical statements submitted to trade publications (Rovenpor, 1993). Similarly, scholars use individuals' consumption, donation, and pastime practices (Aaker, BenetMartinez, \& Garolera, 2001; Barsky et al., 1997; Cain \& McKeon, 2012; Chin, Hambrick, \& Trevino, 2013) as well as whether the individual has children (Dahl, Dezso, \& Ross, 2012) to assess underlying constructs. Ultimately, the sources of information from which scholars could draw to identify individual behaviors are substantial; any source of information regarding individuals' behaviors could be utilized as a measure of an underlying characteristic. For example, advances in technology 
contain archiving capability such as digital video recording (DVR) and global positioning systems (GPS) as well as tracking of Internet browsers and cell phones, which may enable the use of more behavior-based measures, particularly as these technologies become increasingly employed. Data mining experts are already using this information in practice, and scholars may be able to follow suit.

A related approach to using individual behaviors for unobtrusive measurement is the use of behaviors of collectives of individuals. These collective behavior-based measures build upon the rationale that underlying psychological constructs are reflected in behaviors. However, the information used to assess an individual's underlying psychological constructs is drawn from the behaviors of a collective to which the focal individual belongs rather than the individual's behaviors directly. Scholars offer two arguments as to why utilizing collective-level behaviors is viable for assessing psychological constructs of individuals within that collective. First, collectives may become reflective of their members, such as organizations becoming reflective of their employees, particularly those in leadership roles (Hambrick \& Mason, 1984; Schneider, 1987). Thus, analyzing the behaviors of such collectives may provide insight into the psychological constructs of individuals within the collective. Second, a collective's behaviors are in large part affected by the behaviors of individuals within the collective, particularly those in decision-making positions (Carpenter et al., 2004; Finkelstein et al., 2009; Hambrick, 2007; Schneider, Goldstein, \& Smith, 1995). Accordingly, the behaviors of a collective may be indicative of the individuals' underlying personal psychological constructs that drive the collective to behave in such a manner.

The reasoning, then, is similar - the behaviors of collectives are reflective of their individual members, and individual members' behaviors drive the behaviors of the collective. Southwest Airlines serves as an example that underscores both arguments. Not only does the culture at
Southwest attract certain types of individuals, but employee behaviors and the organization's selection processes have reinforced this practice over time as well. As such, Southwest's behaviors may indicate the psychological constructs of individuals the company employs. While the foregoing example focused on the organizational level, the same arguments apply to organizational subgroups such as departments and work teams (e.g., Dougherty, 1992). For clarity, we refer to collective-based measures as anytime information about a collective of individuals serves as the source from which to assess a construct for an individual in the collective.

Multiple collective-level behaviors have been used to measure psychological constructs, particularly for leaders of the collective such as executives. For example, Chatterjee and Hambrick $(2007$, p. 363) utilize the prominence of the CEO's photograph in an organization's annual report to measure narcissism based upon the premise that a "highly narcissistic CEO will seek a great deal of visibility" in company documents like the annual report as both an "exercise of vanity and a strong declaration that he or she is more important than all others in the firm." Similarly, scholars have analyzed the number of official titles bestowed on individuals by their organizations as a measure of the individual's power (Finkelstein, 1992; Harrison, Torres, \& Kukalis, 1988) and a firm's industry-adjusted investment levels to assess the optimism of a CEO (T. C. Campbell et al., 2011). In both instances, the argument is that the organizational-level behavior utilized was indicative of the underlying psychological constructs of an individual within the organization; further, the individual influences the variable to some degree. Due to the depth of available collective-level information, scholars have a variety of options from which to base unobtrusive measures of psychological constructs. For example, Chin et al. (2013) use the degree to which an individual supports the Democratic or Republican political party to measure the individual's liberalism/conservatism. 


\section{Threats to the validity of unobtrusive measures}

Although a number of language- and behaviorbased sources are available to use in unobtrusive measurements of individuals' psychological constructs and scholars increasingly employ such sources, questions have been raised regarding the rigor of inquiries using these approaches (Hiller \& Hambrick, 2005; Hollenbeck et al., 2006; Jin \& Kothari, 2008; Nadkarni \& Herrmann, 2010; Pitcher et al., 2000). We highlight these questions and note the associated threats to the validity of unobtrusive measures of psychological constructs.

\section{Establishing theoretical linkages and eliminating alternatives}

The major question facing users of unobtrusive measures is the difficulty of providing a rationale connecting the measure to the construct that the measure is attempting to assess while simultaneously ruling out other constructs. Thus, a two-part issue arises: providing a theoretical rationale and eliminating alternative explanations based upon a similar rationale. With respect to the former issue, theory supporting the use of a measure of an underlying characteristic is essential. Not only does explaining the theoretical link between the construct and the measure help justify the use of the measure to a discerning reader, but it also establishes that the construct of interest is being meaningfully assessed (Bagozzi \& Phillips, 1982; Blalock, 1971; Edwards \& Bagozzi, 2000). That is, theory helps to establish face and content validity and a logical form of discriminant validity by establishing that the measure logically taps the construct (Hinkin, 1995; Lawshe, 1975).

However, it may be difficult for theory alone to rule out alternatives and hence establish discriminant validity. Consider for example, the possessive words "my" and "mine" and firstperson singular pronouns "I," "me," and "myself" that have been utilized to measure Machiavellianism (Ickes et al., 1986) as well as both narcissism (Chatterjee \& Hambrick, 2007; Raskin \& Shaw, 1988) and self-confidence (Liu, Taffler, \& John, 2009; Rovenpor, 1993). Theoretical rationales may support the notion that possessive words appear in linguistic patterns because of each of these psychological constructs. As a result, it is difficult to determine which characteristic the measure is assessing, a fact that threatens the validity of the measure since it cannot be determined which construct is being measured (D. T. Campbell \& Fiske, 1959; Whitley, 2002). Another example is the use of an individual's stock portfolio decisions as a measure of self-confidence (i.e., the timing of stock option exercise, the purchase and sale of stock in their companies; Malmendier \& Tate, 2005, 2008). Although the theoretical rational behind the use of these measures may be sound - that stock portfolio decisions reflect individuals' confidence in their knowledge of, or ability to increase, the future value of the stock - there are nonetheless other interpretations for such decisions. Portfolio decisions may reflect psychological constructs of the individual like optimism, procrastination, or risk tolerance and/or reflect such elements as the use of inside information to create wealth, the presence of other items in the individuals' investment portfolios, or the optimizing of income tax burdens (T. C. Campbell et al., 2011; Jenter, 2005; Jin \& Kothari, 2008). It may even be an explanation outside the business realm such as the need to pay for a personal expense like a down payment on a home, medical bills, or tuition for a child in college. As such, the fact that decisions to exercise options or purchase additional stock may also reflect various factors both endogenous and exogenous to the individual decreases the validity of the measure because it is not possible to determine whether the behavior results from a particular characteristic (here, self-confidence).

While the issue of discriminant validity in the examples of possessive pronoun usage and stock portfolio behaviors is partially abatable methodologically (e.g., through factor analyses; Hinkin, 1995, 1998), it may be difficult to rule 
out alternative constructs that the unobtrusive measures also assess and hence to isolate the measure of the focal construct. In particular, language-based sources that do not come from the focal individual and behavior-based measures that use information at the collective level face difficulties with ruling out alternatives because the distal nature of the information sources from the construct introduces additional error. With respect to collective behavior-based measures, their use may constitute an ecological fallacy in which observations of a collective are assumed to hold for individuals within the collective (Robinson, 1950), as is the case when inferences about individuals' psychological characteristics are deduced from the information about their group (see Piantadosi, Byar, \& Green, 1988, for a thorough review). Careful consideration should be given to whether this assumption holds true. Similarly, when using language-based sources that do not come directly from the focal individual, care should be exercised with respect to whether the assumption regarding the collective outcome adequately represents the individual. When using words written or spoken directly by a focal individual, the fact that the population of interest (i.e., the individual) is assessed directly can help to eliminate alternatives (Dobbins et al., 1986) and avoid ecological fallacy.

\section{Objectivity of source}

A second obstacle for researchers in using unobtrusive measures is the objectivity of the information source from which the information was drawn. By objectivity, we mean whether the information source possesses the qualities of being accurate and unbiased. If the source is not accurate and unbiased, the degree to which the measure actually assesses the individual's psychological constructs will be compromised. As an illustration, researchers find that people engage in high degrees of impression management (Day et al., 2002), so both their written and spoken words as well as the impressions they present to others and their behaviors may not reflect their true nature. Instead, words, impressions, and behaviors reflect how the individual wants to be perceived (Peluchette, Karl, \& Rust, 2006). This problem is well noted in questionnaire and interview approaches in that impression management or social desirability biases may decrease the validity of measurement (Cook \& Campbell, 1979). However, impression management and social desirability concerns may also plague unobtrusive measures: because individuals intentionally manage impressions, the validity of information sources may likewise be compromised since the measure may be based on information that is less than accurate and contains bias (e.g., Brown \& Sarma, 2007; Malmendier \& Tate, 2005). For example, people have much to gain by portraying specific images in order to affect outcomes such as their compensation and their ability to secure employment (Bolino et al., 2008). As a result, basing assessments of underlying psychological constructs on potentially inaccurate and biased information decreases the validity of the measure. In particular, proxy statements, press releases, letters to shareholders, and board meeting minutes are typically edited to portray the organization and its executives in a particular light, depending on the situation (McEachern, 1998; Roverpor, 1993; Salancik \& Meindl, 1984). Thus, the use of these sources in assessments of executive psychological constructs, as is commonplace, may introduce confounds into the measures that threaten validity. The same problem extends to the use of information sources at lower levels of the organizational hierarchy as well since e-mails, memos, and other correspondence may be subject to personal manipulations. As such, like questionnaires and interviews, social desirability and/or impression management may threaten the validity of unobtrusive measures based upon these sources.

Similarly, questions exist regarding the objectivity (i.e., the accurate and unbiased nature) of using the words of others to assess a focal individual's psychological constructs. Although gaining an alternative assessment may be the strength of this methodology, the validity of 
these measures decreases when the objectivity of the sources is limited by inaccuracy and/or bias. Consider the use of media reports as a case in point. Although the media should offer an objective assessment of the situation that closely reflects actual events, whether the media does present an objective view is debatable, particularly in light of the rise of news-based entertainment shows that may present slanted coverage to generate an audience (Gans, 2005; Koh, 2010). Further, individuals may engage in behaviors that bias media accounts (Westphal \& Deephouse, 2011; Westphal, Park, McDonald, \& Hayward, 2012). The same may be said of using such sources at lower levels in the organization where individuals may paint others in a more favorable or negative light for various reasons (Bolino et al., 2008). Thus, measures based on this inaccurate and biased information in turn threatens the validity of the resulting measures. For instance, consider the use of presentencing investigative reports provided by prosecuting and defending attorneys (e.g., Langton \& Piquero, 2007; Wheeler et al., 1982). Although these reports offer information on individuals in the court cases that is otherwise difficult to obtain, it is possible that both prosecuting and defending legal teams are not objective information sources with respect to a client/criminal. Independent of actual intent to present information in an inaccurate and biased fashion, human beings are imperfect and their statements and assessments are imperfect representations of reality (Chen \& Meindl, 1991; Hamilton \& Zeckhauser, 2004; Winter, 1987a), a fact that may further hinder the validity of using such assessments.

\section{Context}

A third concern with using unobtrusive measures is that contextual effects bias information sources. For instance, individuals and/or collectives "may vary the content of their message depending on the particular audience, time, or setting" (Rovenpor, 1993, p. 37). For example, individuals may wish to "hype major events" and/or "project an aura" at a particular time to affect the outcome of future events (Brown \& Sarma, 2007, p. 363). Consider measures based upon political speeches (e.g., DeGroot, Aime, Johnson, \& Kluemper, 2011; House et al., 1991; Winter, 1987b, 1993) which are noted for being altered to a large degree based upon contextual factors such as timing and audience (Morris, 2001; Westphal \& Deephouse, 2011; Williams, 1981). Accordingly, measures developed based upon this information may reflect contextual components that increase the noise associated with the assessment of the intended construct. Scholars must consider the original purpose of the information source to determine whether that information is a good source from which to measure the intended construct. The likelihood is that unobtrusive information sources are produced with other purposes in mind - that is, words utilized are not chosen with the purpose of allowing assessment of personal psychological constructs. In the same fashion, behaviors are not undertaken to allow subsequent analysis. Thus, the reason that the information was documented is an important contextual consideration. In sum, scholars need to consider both context and whether a factor associated with the information systematically affects whether the information serves as a good source for unobtrusive measurement.

\section{Sample selection and availability}

Fourth, sample selection and availability are threats that relate to the two previous concerns (objectivity of the source and context). Given that unobtrusive measures can only be applied to instances when information is available, a naturally occurring selection bias happens that can decrease the value of such measures (Hamilton $\&$ Zeckhauser, 2004). For instance, information availability may serve to bias measurement; a reclusive individual (e.g., Howard Hughes) may have fewer sources from which to draw while an individual who makes information widely available (e.g., Kim Kardashian) would have 
more information from which to draw (Winter, 2005). Likewise, other factors may skew the availability of information, such as choices with respect to keeping or deleting archival information (J. Edgar Hoover, as an extreme example). As a result, sample selection and availability often work hand in hand - systematic variance in the availability (or lack thereof) of sources from which to draw is likely, and the sources available may be biased or possess limited information.

As a case in point, in the US, laws require that public corporations report the annual salary of top earners. Not only does this differ systematically from private firms, which are not required to share such information, thus creating a naturally occurring selection bias, but also public corporations often do not report how often or in what increments these top earners receive their pay. If compensation-related decisions such as annual pay amounts and stock option exercise are indeed indicative of underlying psychological constructs (Chatterjee \& Hambrick, 2007, 2011; Hayward \& Hambrick, 1997; Malmendier \& Tate, 2005, 2008), it may be possible that how such information is reported confounds accurate measurement. That is, the timing of data reporting regarding individual's behaviors (e.g., taxes; Jin \& Kothari, 2008) and the lumpiness of information reporting (e.g., option exercises are reported in aggregate over a year, not in increments throughout the year) may affect the degree to which scholars can relate the information to an underlying individual construct. Further, even when similar information is available, reporting it is not always uniform in timing, scope, or format. Since only certain information is available and selection is based upon its being available, the accuracy of unobtrusive measures may be compromised to some degree by sample selection and availability.

\section{Parsing out the individual}

A last problem with unobtrusive measures is that in certain instances it is difficult to parse out the effect of individual members. The most prevalent example is using collective-level information in which the degree to which the information is indicative of the individual may be tenuous. For example, researchers find that various members within an organization or group affect the behavior of that collective, particularly those in decision-making roles (e.g., Dougherty, 1992; Finkelstein et al., 2009; Johnson, Schnatterly, \& Hill, 2013). However, it may not be possible to identify the unique contributions of certain members, and thus our ability to assess individual psychological constructs from collective-level data is limited. That is, assigning information to a single individual despite the joint nature of the information without adjusting for the individual's relative contribution decreases the validity of such assessments. This is problematic for research aimed at extending the impact of psychological constructs of individual group members, such as to non-CEO members of the top management team (e.g., Aime, Johnson, Ridge, \& Hill, 2010; Menz, 2012). For example, an emerging research stream focused on the traits of the chief operating officer (COO) has developed (Hambrick \& Cannella, 2004; Zhang, 2006) while other researchers have extended research of psychological constructs to the chief financial officer as well (CFO; Glaser, Schafers, \& Weber, 2008; Jensen \& Zajac, 2004). If a researcher was interested in the effects of a group as a whole, certain language-based and collective behavior-based measures may be useful for group-level measures but may not be viable, or least may contain additional noise, for individual analyses.

\section{Recommendations to enhance unobtrusive measurement of psychological constructs}

All measurement approaches have both merits and limitations. Regardless of approach, it is important that scholars understand how to use the measures effectively to accentuate the positive aspects and avoid as many pitfalls as possible. With this in mind, we recommend 
some practices to employ that can enhance the effectiveness of unobtrusive measurement of psychological constructs. These practices are summarized in Table 3.

\section{Two foundational recommendations: Theoretical and methodological grounding}

Critiques of unobtrusive measures often note the lack of theoretical and methodological rigor; hence, we foremost recommend practices for addressing these interrelated concerns that are foundational to good measurement. A theoretical rationale should be provided to connect the measure to the construct the measure is purportedly assessing (Bagozzi \& Phillips, 1982; Blalock, 1971; Edwards \& Bagozzi, 2000). Although using theory to connect the measure to the construct being assessed is a normative imperative, this imperative is at times not met. For example, Hiller and Hambrick (2005) note that investigations of hubris - many of which have been conducted using unobtrusive measures (e.g., Bollaert \& Petit, 2010; Hill, Kern, \& White, 2012; Petit \& Bollaert, 2012) — have been marked by a lack of rigorous psychological grounding. Benefits of unobtrusive measurement may be lost if the measures are not well grounded, as theory helps to establish face and content validity (Hinkin, 1995; Lawshe, 1975), thus providing the logic supporting the notion that the construct is being tapped by the measure. The need for theoretical grounding is perhaps most glaring in areas in which a psychological construct of an individual is measured from information that is collective in nature - whether that is language or behaviorsas such situations need two layers of theoretical linkages: first, theory linking the information utilized to the construct; and second, theory linking the collective-level information to the individual, which may constitute an ecological fallacy. Alternately, collective-level information can be used to measure collective-level constructs (e.g., group values or cognitions), and an appropriate theoretical rationale must be provided to remove the potential confound of inferring individual constructs from collective information.

Unobtrusive measures also need firm methodological grounding. We note several approaches for providing methodological rigor for an unobtrusive measure. As Webb et al. (1966, p. 174) note, unobtrusive measures by their very nature possess "more rival plausible hypotheses," and hence "more risk" than do other quantitative approaches. Plainly put, unobtrusive measures may face concerns that the measure is not tapping the focal construct in isolation, but rather is tapping a similar or different construct. Yet, like qualitative approaches that are subject to similar concerns, steps can be taken to help isolate the phenomenon of interest (Bansal \& Corley, 2011, 2012). While the most ardent skeptic may never be swayed and not all possible alternatives may be ruled out, we note three primary ways to accumulate evidence that an unobtrusive measure is assessing the focal construct.

First, small samples of academic and/or practitioner subject matter experts can serve as raters to determine whether they believe that a selected measure assesses an intended construct (Anderson \& Gerbing, 1991; Govindarajan \& Kopalle, 2006; Hambrick, 1981; Hambrick \& Abrahamson 1995; Hinkin \& Schriesheim, 1989; Mackenzie, Podsakoff, \& Fetter, 1991; Schriesheim, Powers, Scandura, Gardiner, \& Lankau, 1993; Subramaniam \& Venkatraman, 2001). For example, Nadkarni and Narayanan (2007b) consulted 14 industry analysts and 14 strategy professors as they developed a measure; such approaches are common in the development of items for questionnaires (Hinkin, 1995). Studies using unobtrusive measures can follow suit and obtain evidence a priori that the measure intended for use has content validity in the eyes of raters before applying the measure to a broader sample (Lawshe, 1975).

Second, convergence, divergence, and robustness across measures can be assessed. A benefit of unobtrusive measures is that they allow scholars to utilize a multitude of data sources. Scholars should leverage this benefit by 
Table 3. Recommendations to enhance unobtrusive measurement.

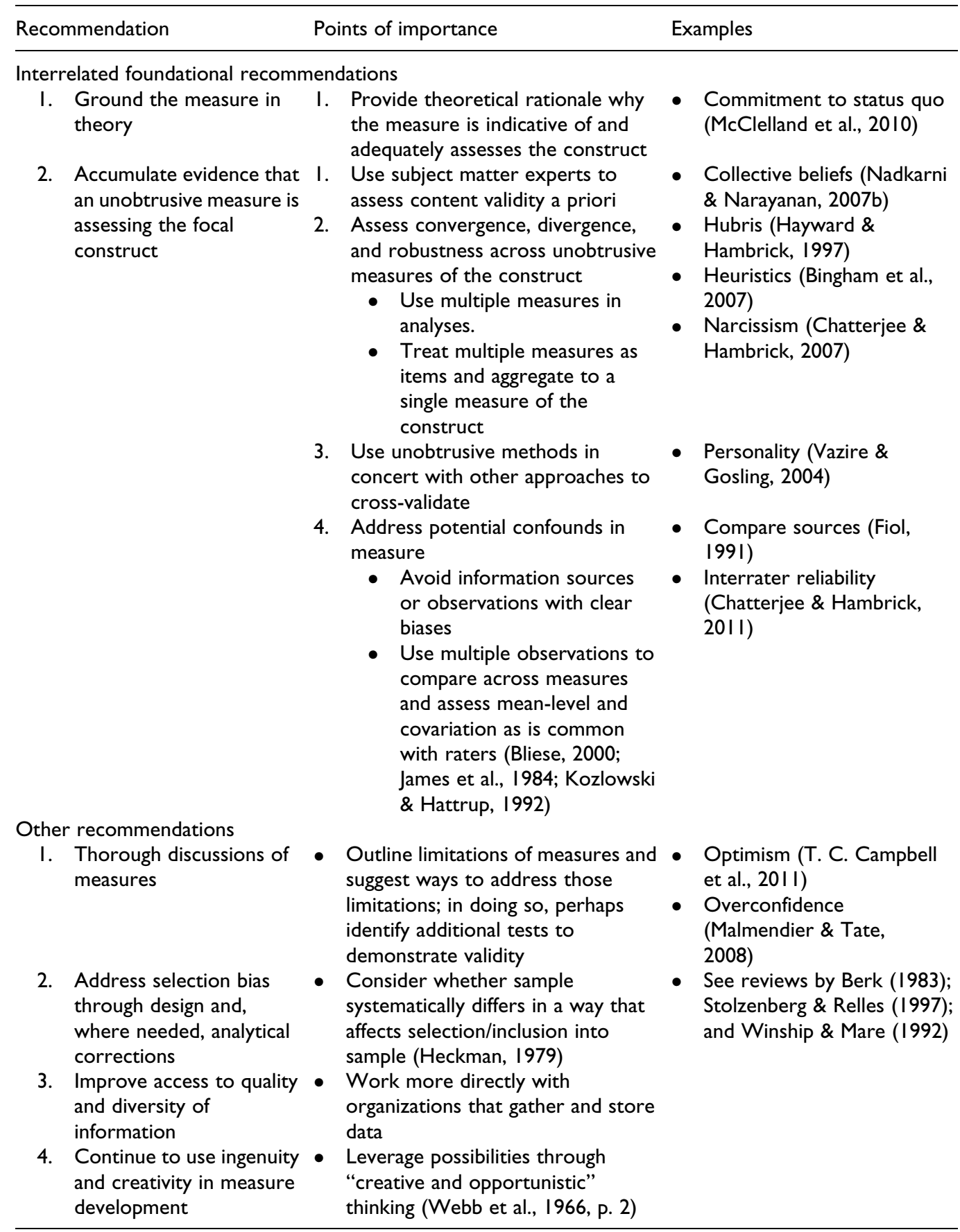


demonstrating that multiple unobtrusive measures converge, that measures of other constructs diverge, and further that the analyses are robust across various measures of the same construct. For example, noting the limitations of a single unobtrusive measure of a psychological construct, several scholars have employed multiple measures and interpreted results across measures through triangulation or factor analysis (Bingham, Eisenhardt, \& Farr, 2007; Chatterjee \& Hambrick, 2007, 2011; Hayward \& Hambrick, 1997; Hill, 1995; Malmendier \& Tate, 2005, 2008). Similarly, like the measurement of psychological constructs using survey instruments, scholars can treat individual unobtrusive measures as items and use appropriate psychometric practices to assess whether the measures can be aggregated (e.g., Hinkin, 1995, 1998). Scholars should consider the theoretical rationale of the unobtrusive measures treated as an "item" prior to aggregation to make sure that items are specified in the same fashion, however. That is, some unobtrusive measures rely on reflective logic while others rely on formative logic. Researchers should not include both formative and reflective items in aggregated measures and should consider whether formative measurement of the focal construct is warranted (see for example, Diamantopoulos, Riefler, \& Roth, 2008; Edwards, 2011).

Third, scholars can employ unobtrusive measures in concert with other measurement approaches to cross-validate (Campbell \& Fiske, 1959; Creswell, 2007; Edmondson \& McManus, 2007). For example, scholars can attempt to measure constructs via questionnaires using validated instruments and compare results with those from unobtrusive assessments in order to assess validity. Barsky et al. (1997) work assessing individuals' risk tolerance serves as a good example of the latter approach. They first measure focal individuals' responses using a validated survey instrument and then relate those responses to various behaviors (smoking, drinking, purchasing insurance, and investing strategies). These behaviors in turn serve as the basis of subsequent unobtrusive measures of risk tolerance (e.g., Cronqvist et al., 2012; Dohmen et al., 2005). This approach to cross-validation may be insightful to others wishing to validate unobtrusive measures as well. Research by Vazire and Gosling (2004) cross-validating measures across approaches is also informative.

As an added benefit of using multiple measures (whether multiple unobtrusive measures or using unobtrusive measures in concert with other approaches), as Carter, Daniels, and Zickar (2013) note, is that this approach helps avoid the philosophical deadlock that occurs when only one type of evidence is provided since only scholars who believe in the validity of the approach used will be convinced. Rather, given the multitude of unobtrusive measures possible, using several in concert and crossvalidating with other approaches can help sway skeptics of any single measure or approach.

Beyond determining whether the unobtrusive measure adequately assesses the focal construct and not others, several methods can be employed to remove other confounds as well. Along these lines, our fourth recommendation is that scholars employ sound methodology to address confounds associated with the context in which the information that is utilized was initially collected. Depending on the information source utilized to develop an unobtrusive measure, the contextual conditions associated with that information may alter the content and hence confound measurement. Scholars can address this by giving careful consideration to which information source they use, with emphasis on avoiding information sources or observations of a source that have clear biases. Beyond exercising care to avoid selecting information with obvious confounds, using multiple observations can help purify the measure to contextual effects. For example, multiple observations of the same language source (e.g., letters to shareholders or e-mails) can help determine whether the language utilized is consistent across different observations of the same information source over time. For example, Fiol 
(1991) uses both annual statements and internal company documents, finding that the two did not differ significantly. Such an approach helps to provide evidence that confounds associated with the source are not biasing measurement. Similarly, using multiple observations across multiple language sources (e.g., using a memo and a biographical statement) can help to determine whether language used is similar across mediums. Such determinations can be made by making mean-level and covariation assessments to provide evidence that the context of any single observation is not biasing the measure, much as is done with raters (Bliese, 2000; James, Demaree, \& Wolf, 1984; Kozlowski \& Hattrup, 1992).

\section{Other recommendations}

Beyond the interrelated foundational recommendations for improving measurement, we note four suggestions for researchers who wish to employ unobtrusive measures in future research. First, unobtrusive measurement would benefit from a more thorough discussion of the measures, particularly with respect to both potential limitations and the presence of any alternative explanations. Although journal space is often limited, expanding the discussion of the measures serves multiple purposes: it may help the researchers identify post hoc analyses they can conduct to either address the limitations of a measure or rule out alternatives; it may help others identify ways to improve measures in future research; and finally, it may improve the paper in the eyes of the readers. As Geletkanycz and Tepper (2012) argue in an editorial on publishing, the best discussion sections outline limitations and suggest future research to address those limitations. We view the work of Malmendier and Tate $(2005,2008)$ as a good example of discussing various factors that confound their measure of overconfidence based upon option exercise. Not only were the authors able to address some limitations in post hoc tests, but subsequent work has been able to address limitations in their measurement (T. C. Campbell et al., 2011; Jin \& Kothari, 2008); further, this conforms with the Geletkanycz and Tepper recommendations on improving the paper for the reader.

Second, scholars need to consider selection bias either through careful design or through analyses using Heckman (1979) style selection corrections where necessary. Although a full discussion of selection bias is outside the scope of this article, if systematic selection into the sample is based upon information availability, then to the degree that this creates a systematic relationship with the variable of interest, the focal relationship may be biased by selection (for comprehensive reviews, see Berk, 1983; Stolzenberg \& Relles, 1997; Winship \& Mare, 1992). Selection bias will be more pressing in certain contexts than in others. For example, a representative sample of language usage from social media (e.g., Facebook, Twitter) may have a degree of naturally occurring selection bias in that access to the technology and subsequent knowledge to post on social media is not uniform across individuals in society. However, scholars should consider whether selection into the sample and/or the information source systematically varies across subjects and the degree to which this confounds the internal validity of their measures (see also Cook \& Campbell, 1979, with respect to the effects of selective assignment into the study).

Third, researchers would be well served to consider ways to improve their access to and quality of unobtrusive information sources. Not only can additional access to data help with the development of unobtrusive measures, but thinking about how to capture quality information may also be beneficial. For example, scholars may want to consider collaborating with organizations, appealing to managers or boards of directors, and working with firms to provide some service in return for participation (e.g., training, consulting, data analyses) to gain access to information sources. This is not to suggest that partnerships are always beneficial as involving a partner may lead to other 
problems in design and practical implementation that scholars wish to avoid. With that said, given that unobtrusive measures often draw upon data created for some other purpose, scholars can certainly benefit from working more directly with organizations that gather and store data to improve both access to and quality of information at their disposal.

Lastly, although extant approaches offer a sound foundation for scholars to draw upon as they seek to assess psychological constructs of individuals with unobtrusive measures, future investigators should build upon the techniques highlighted here. As many of the measures illustrate, researchers employ a great deal of ingenuity and creativity in unobtrusive measures. We join Webb et al. (1966, p. 2) in espousing "creative and opportunistic" thinking to identify measurement possibilities, as these traits will be of benefit in future investigations as well, particularly in light of the increasing availability of both information and processing capability that may enable scholars to tap new sources of information in assessing individuals' psychological constructs. So long as sound theoretical linkages can be drawn to the underlying characteristic being investigated (that is, that they are grounded in theory) and steps are taken to ensure validity, there are few bounds to how scholars can assess psychological constructs.

\section{Conclusion}

Measurement of psychological constructs in organizational research has been dominated by the use of a limited number of approachesnamely, those that require the cooperation of either a focal subject or an alternate respondent who knows the focal subject (Morgeson et al., 2007; Oh et al., 2011; Ones et al., 2007; Zimmerman et al., 2010). We highlight an alternative approach to measuring psychological constructs that does not require a respondent's cooperation - using unobtrusive measures - and offer several recommendations for effectively employing them. While effective employment of unobtrusive measures offers scholars several benefits, these approaches are by no means a "be all, end all" for measuring psychological constructs. Rather, various approaches to measurement are necessary to more fully develop our understanding of the role of individual psychology in organizations. Given the increased availability of, and ability to capture, information from which to base unobtrusive measures coupled with limitations inherent in any measurement approach, much can be gained by leveraging opportunities for unobtrusive measurement in future research.

\section{References}

Aaker, J. L., Benet-Martinez, V., \& Garolera, J. (2001). Consumption symbols as carriers of culture: A study of Japanese and Spanish brand personality constructs. Journal of Personality and Social Psychology, 81, 492-508.

Aime, F., Johnson, S., Ridge, J., \& Hill, A. (2010). The routine may be stable but the advantage is not: Competitive implications of key employee mobility. Strategic Management Journal, 31, $75-87$.

Alison, L. J., Snook, B., \& Stein, K. L. (2001). Unobtrusive measurement: Using police information for forensic research. Qualitative Research, $1,241-254$.

Allport, F. H. (1937). The observation of societal behaviors of individuals. Social Forces, 15, 484-487.

American Psychological Association. (2010). Ethical principles of psychologists and code of conduct. Retrieved from http://www.apa.org/ethics/ code/index.aspx

Anderson, J. C., \& Gerbing, D. W. (1991). Predicting the performance of measures in a confirmatory factor-analysis with a pretest assessment of their substantive validities. Journal of Applied Psychology, 76, 732-740.

Anseel, F., Lievens, F., Schollaert, E., \& Bhoragwicka, B. (2010). Response rates in organizational science, 1995-2008: A meta-analytic review and guidelines for survey researchers. Journal of Business and Psychology, 25, 335-349. 
Ashforth, B. E., Gioia, D. A., Robinson, S. L., \& Trevino, L. K. (2008). Re-viewing organizational corruption - Introduction. Academy of Management Review, 33, 670-684.

Back, M. D., Stopfer, J. M., Vazire, S., Gaddis, S., Schmukle, S. C., Egloff, B., \& Gosling, S. D. (2010). Facebook profiles reflect actual personality not self-idealization. Psychological Science, 21, 372-374.

Bagozzi, R. P., \& Phillips, L. W. (1982). Representing and testing organizational theories: A holistic construal. Administrative Science Quarterly, 7, 459-489.

Bansal, P., \& Corley, K. (2011). The coming of age for qualitative research: Embracing the diversity of qualitative methods. Academy of Management Journal, 54, 233-237.

Bansal, P., \& Corley, K. (2012). Publishing in AMJ-Part 7: What's different about qualitative research? Academy of Management Journal, 55, 509-513.

Barsky, R. B., Juster, F. T., Kimball, M. S., \& Shapiro, M. D. (1997). Preference parameters and behavioral heterogeneity: An experimental approach in the health and retirement study. Quarterly Journal of Economics, 112, 537-579.

Becker, T. M., \& Meyers, P. R. (1974). Empathy and bravado: Interviewing reluctant bureaucrats. The Public Opinion Quarterly, 38, 605-613.

Berk, R. A. (1983). An introduction to sample selection bias in sociological data. American Sociological Review, 48, 386-398.

Bettman, J. R., \& Weitz, B. A. (1983). Attributions in the board room: Causal reasoning in corporate annual reports. Administrative Science Quarterly, 28, 165-183.

Bingham, C. B., Eisenhardt, K. M., \& Farr, N. R. (2007). What makes a process a capability? Heuristics, strategy and effective capture of opportunities. Strategic Entrepreneurship Journal, 1, 27-47.

Blalock, H. M. (1971). Causal models involving unobserved variables in stimulus-response situations. In H. M. Blalock (Ed.), Causal models in the social sciences (pp. 335-347). Chicago, IL: Aldine.

Bliese, P. D. (2000). Within-group agreement, nonindependence, and reliability: Implications for data aggregation and analysis. In K. J. Klein \& S. W. J. Kozlowsk (Eds.). Multilevel theory, research, and methods in organizations (pp. 349-381). San Francisco, CA: Jossey-Bass.

Bolino, M. C., Kacmar, K. M., Turnley, W. H., \& Gilstrap, J. B. (2008). A multi-level review of impression management motives and behaviors. Journal of Management, 34, 1080-1109.

Bollaert, H., \& Petit, V. (2010). Beyond the dark side of executive psychology: Current research and new directions. European Management Journal, 28, 362-376.

Brown, R., \& Sarma, N. (2007). CEO overconfidence, CEO dominance and corporate acquisitions. Journal of Economics and Business, 59, 358-379.

Brundin, E., \& Nordqvist, M. (2008). Beyond facts and figures: The role of emotions in boardroom dynamics. Corporate Governance: An International Review, 16, 326-341.

Brunswik, E. (1956). Perception and the representative design of psychological experiments (2nd ed.). Berkeley: University of California Press.

Cain, M. D., \& McKeon, S. B. (2012). Cleared for takeoff? CEO personal risk-taking and corporate policies. Working paper, University of Notre Dame, South Bend, IN.

Campbell, D. T., \& Fiske, D. W. (1959). Convergent and discriminant validation by the multitraitmultimethod matrix. Psychological Bulletin, 56, 81-105.

Campbell, T. C., Gallmeyer, M., Johnson, S. A., Rutherford, J., \& Stanley, B. W. (2011). CEO optimism and forced turnover. Journal of Financial Economics, 101, 695-712.

Carpenter, M. A., Geletkanycz, M. A., \& Sanders, W. G. (2004). Upper echelons research revisited: Antecedents, elements, and consequences of top management team composition. Journal of Management, 30, 749-778.

Carter, N. T., Dala, D. K., Lake, C. J., Lin, B. C., \& Zickar, M. J. (2011). Using mixed-model item response theory to analyze organizational survey responses: An illustration using the Job Descriptive Index. Organizational Research Methods, 14, 116-146. 
Carter, N. T., Daniels, M. A., \& Zickar, M. J. (2013). Projective testing: Historical foundations and uses for human resource management. Human Resource Management Review, 23, 205-218.

Chatterjee, A., \& Hambrick, D. C. (2007). It's all about me: Narcissistic chief executive officers and their effects on company strategy and performance. Administrative Science Quarterly, 52, 351-386.

Chatterjee, A., \& Hambrick, D. C. (2011). Executive personality, capability cues, and risk taking: How narcissistic CEOs react to their successes and stumbles. Administrative Science Quarterly, 56, 202-237.

Chen, C. C., \& Meindl, J. R. (1991). The construction of leadership images in the popular press: The case of Burr, Donald and People Express. Administrative Science Quarterly, 36, 521-551.

Chin, M. K., Hambrick, D. C., \& Trevino, L. K. (2013). Political ideologies of CEOs: The influence of executives' values on corporate social responsibility. Administrative Science Quarterly, 58, 197-232.

Cohn, M. A., Mehl, M. R., \& Pennebaker, J. W. (2004). Linguistic markers of psychological change surrounding September 11, 2001. Psychological Science, 15, 687-693.

Combey, P. (1980). A tracer approach to the study of organizations. Journal of Management Studies, 17, 96-126.

Cook, T. C., \& Campbell, D. T. (1979). Quasiexperimentation: Design and analysis issues for field settings. Chicago, IL: Rand McNally.

Creswell, J. W. (2007). Research design: Qualitative, quantitative, and mixed methods approaches. Thousand Oaks, CA: Sage.

Cronqvist, H., Makhiga, H., \& Yonker, S. E. (2012). Behavioral consistency in corporate finance: CEO personal and corporate leverage. Journal of Financial Economics, 103, 20-40.

Cycyota, C. S., \& Harrison, D. A. (2002). Enhancing survey response rates at the executive level: Are employee or consumer-level techniques effective? Journal of Management, 28, 151-177.

Cycyota, C. S., \& Harrison, D. A. (2006). What (not) to expect when surveying executives: A meta- analysis of top manager response rates. Organizational Research Methods, 9, 133-160.

Dahl, M. S., Dezso, C. L., \& Ross, D. G. (2012). Fatherhood and managerial style: How a male CEO's children affect the wages of his employees. Administrative Science Quarterly, 57, 669-693.

Dalziel, T., Gentry, R. J., \& Bowerman, M. (2011). An integrated agency-resource dependence view of the influence of directors' human and relational capital on firms' R\&D spending. Journal of Management Studies, 48, 1217-1242.

D'Aveni, R. A., \& MacMillan, I. C. (1990). Crisis and the content of managerial communications: A study of the focus of attention of top managers in surviving and failing firms. Administrative Science Quarterly, 35, 634-657.

Davison, H. K., Maraist, C. C, \& Bing, M. N. (2011). Friend or foe? The promise and pitfalls of using social networking sites for HR decisions. Journal of Business and Psychology, 26, 153-159.

Davison, H. K., Maraist, C. C., Hamilton, R., \& Bing, M. N. (2012). To screen or not to screen? Using the Internet for selection decisions. Employee Responsibilities and Rights Journal, 24, 1-21.

Day, D. V., Schleicher, D. J., Unckless, A. L., \& Hiller, N. J. (2002). Self-monitoring personality at work: A meta-analytic investigation of construct validity. Journal of Applied Psychology, 87, 390-401.

DeCelles, K. A., DeRue, D. S., Margolis, J. D., \& Ceranic, T. L. (2012). Does power corrupt or enable? When and why power facilitates selfinterested behavior. Journal of Applied Psychology, 97, 681-689.

DeGroot, T., Aime, F., Johnson, S. G., \& Kluemper, D. (2011). Does talking the talk help walking the walk? An examination of the effect of vocal attractiveness in leader effectiveness. The Leadership Quarterly, 22, 680-689.

Diamantopoulos, A., Riefler, P., \& Roth, K. P. (2008). Advancing formative measurement models. Journal of Business Research, 61, 1203-1218.

Dobbins, G. H., Lane, I. M., \& Steiner, D. D. (1986). A note on the role of laboratory methodologies in applied behavioural research: Don't throw out the 
baby with the bath water. Journal of Organizational Behavior, 9, 281-286.

Dohmen, T., Falk, A., Huffman, D., Sunde, J., Schupp, J., \& Wagner, G. G. (2005). New evidence from a large, representative, experimentallyvalidated survey. Institute for the Study of Labor Discussion Paper 1730.

Dougherty, D. (1992). Interpretive barriers to successful product innovation in large firms. Organization Science, 3, 179-202.

Dundon, T., \& Ryan, P. (2010). Interviewing reluctant respondents: Strikes, henchmen, and Gaelic games. Organizational Research Methods, 13, 562-581.

Duriau, V. J., Reger, R. K., \& Pfarrer, M. D. (2007). A content analysis of the content analysis literature in organization studies: Research themes, data sources and methodological refinements. Organizational Research Methods, 10, 5-34.

Edmondson, A. C., \& McManus, S. E. (2007). Methodological fit in management field research. Academy of Management Review, 32, 1155-1179.

Edwards, J. R. (2011). The fallacy of formative measurement. Organizational Research Methods, 14, 370-388.

Edwards, J. R., \& Bagozzi, R. P. (2000). On the nature and direction of relationships between constructs and measures. Psychological Methods, 5, 155-174.

Ferris, D. L., Brown, D. J., Berry, J. W., \& Lian, H. (2008). The development and validation of The Workplace Ostracism Scale. Journal of Applied Psychology, 93, 1348-1366.

Ferris, G. R., Blass, F. R, Douglas, C., Kolodinsky, R. W., \& Treadway, D. C. (2003). Personal reputation in organizations. In J. Greenberg (Ed.), Organizational behavior: The state of the science (2nd ed., pp. 216-246). Mahwah, NJ: Lawrence Erlbaum Associates.

Finkelstein, S. (1992). Power in top management teams: Dimensions, measurement, and validation. Academy of Management Journal, 35, 505-538.

Finkelstein, S., Hambrick, D. C., \& Cannella, A. A. (2009). Strategic leadership: Theory and research on executives, top management teams, and boards. New York, NY: Oxford.

Fiol, C. M. (1991). Managing culture as a competitive resource: An identity-based view of sustainable competitive advantage. Journal of Management, 17, 191-211.

Funder, D. C., \& Colvin, C. R. (1991). Explorations in behavioral consistency: Properties of persons, situations, and behaviors. Journal of Personality and Social Psychology, 60, 773-794.

Galtving, J. (1967). Theory and methods of social research. Oslo, Norway: Universitetsforlaget.

Gans, H. J. (2005). Deciding what's news: A study of CBS Evening News, NBC Nightly News, Newsweek, and Time. Evanston, IL: Northwestern University Press.

Geletkanycz, M., \& Tepper, B. J. (2012). Publishing in AMJ-Part 6: Discussing the implications. Academy of Management Journal, 55, 256-260.

Gibson, F. W., Fiedler, F. E., \& Barrett, K. M. (1993). Stress, babble, and the utilization of the leader's intellectual abilities. The Leadership Quarterly, 4, 189-208.

Glaser, M., Schafers, P., \& Weber, M. (2008). Managerial optimism and corporate investment: Is the CEO alone responsible for the relation? Working paper, University of Mannheim, Germany.

Goffman, E. (1959). The presentation of self in everyday life. New York, NY: Doubleday and Co.

Golden-Biddle, K., \& Rao, H. (1997). Breaches in the boardroom: Organizational identity and conflicts of commitment in a nonprofit organization. Organization Science, 8, 593-611.

Gosling, S. D., Ko, S. J., Mannarelli, T., \& Morris, M. E. (2002). A room with a cue: Personality judgments based on offices and bedrooms. Journal of Personality and Social Psychology, 82, 379-398.

Govindarajan, V., \& Kopalle, P. K. (2006). Disruptiveness of innovations: Measurement and an assessment of reliability and validity. Strategic Management Journal, 27, 189-199.

Hambrick, D. C. (1981). Environment, strategy and power within top management teams. Administrative Science Quarterly, 26, 253-275.

Hambrick, D. C. (2007). Upper echelons theory: An update. Academy of Management Review, 32, 334-343.

Hambrick, D. C., \& Abrahamson, E. (1995). Assessing managerial discretion across industries: A multi-method approach. Academy of Management Journal, 38, 1427-1441. 
Hambrick, D. C., \& Cannella, A. A. (2004). CEOs who have COOs: Contingency analysis of an unexplored structural form. Strategic Management Journal, 25, 959-979.

Hambrick, D. C., \& Mason, P. A. (1984). Upper echelons: The organization as a reflection of its top managers. Academy of Management Review, 9, 193-206.

Hamilton, J. T., \& Zeckhauser, R. (2004). Media coverage of CEOs: Who? What? Where? When? Why? Draft prepared for the Workshop on the Media and Economic Performance, Stanford Institution for International Studies, Center on Development, Democracy, and the Rule of Law. Retrieved from http://www.anderson.ucla. edu/faculty_pages/romain.wacziarg/mediapapers/ HamiltonZeckhauser.pdf

Harrison, J. R., Torres, D. L., \& Kukalis, S. (1988). The changing of the guard: Turnover and structural change in the top-management positions. Administrative Science Quarterly, 33, 211-232.

Hayward, M. L. A., \& Hambrick, D. C. (1997). Explaining the premiums paid for large acquisitions: Evidence of CEO hubris. Administrative Science Quarterly, 42, 103-127.

Heckman, J. (1979). Sample selection bias as a specification error. Econometrica, 47, 153-161.

Hill, A. D., Kern, D. A., \& White, M. A. (2012). Building understanding in strategy research: The importance of employing consistent terminology and convergent measures. Strategic Organization, 10, 187-200.

Hill, S. (1995). The social organization of boards of directors. British Journal of Sociology, 46, 245-278.

Hiller, N. J., \& Hambrick, D. C. (2005). Conceptualizing executive hubris: The role of (hyper-) core self-evaluations in strategic decision making. Strategic Management Journal, 26, 297-319.

Hinkin, T. R. (1995). A review of scale development practices in the study of organizations. Journal of Management, 21, 967-988.

Hinkin, T. R. (1998). A brief tutorial on the development of measures for use in survey questionnaires. Organizational Research Methods, 1, 104-121.
Hinkin, T. R., \& Schriesheim, C. A. (1989). Development and application of new scales to measure the French and Raven (1959) bases of social power. Journal of Applied Psychology, 74, 561-567.

Hirsch, P., \& Pozner, J. (2005). To avoid surprises, acknowledge the dark side: Illustrations from securities analysts. Strategic Organization, 3, 229-238.

Hollenbeck, J. R., DeRue, D. S., \& Mannor, M. (2006). Statistical power and parameter stability when subjects are few and tests are many: Comment on Peterson, Smith, Martorana, and Owens (2003). Journal of Applied Psychology, 91, 1-5.

House, R. J., Spangler, W. D., \& Woycke, J. (1991). Personality and charisma in the U.S. presidency: A psychological theory of leader effectiveness. Administrative Science Quarterly, 36, 364-396.

Ickes, W., Reidhead, S., \& Patterson, M. (1986). Machiavellianism and self-monitoring: As different as me and you. Social Cognition, 4, 58-74.

Insch, G. S., Moore, J. E., \& Murphy, L. D. (1997). Content analysis in leadership research: Examples, procedures, and suggestions for future use. Leadership Quarterly, 8, 1-25.

James, L. R., Demaree, R. G., \& Wolf, G. (1984). Estimating within-group interrater reliability with and without response bias. Journal of Applied Psychology, 69, 85-98.

Jensen, M., \& Zajac, E. J. (2004). Corporate elites and corporate strategy: How demographic preferences and structural position shape the scope of the firm. Strategic Management Journal, 25, 507-524.

Jenter, D. (2005). Market timing and managerial portfolio decisions. The Journal of Finance, 60, 1903-1949.

Jin, L., \& Kothari, S. P. (2008). Effects of personal taxes on managers' decisions to sell their stock. Journal of Accounting and Economics, 46, 23-46.

Johnson, S. G., Schnatterly, K., \& Hill, A. D. (2013). Board composition beyond independence: Social capital, human capital, and demographics. Journal of Management, 39, 232-262.

Kluemper, D. H., \& Rosen, P. A. (2009). Future employment selection methods: Evaluating social 
networking web sites. Journal of Managerial Psychology, 24, 567-580.

Kluemper, D. H., Rosen, P. A., \& Mossholder, K. W. (2012). Social networking websites, personality ratings, and the organizational context: More than meets the eye? Journal of Applied Social Psychology, 42, 1143-1172.

Koh, K. (2010). Value or glamour? An empirical investigation of the effect of celebrity CEOs on financial reporting practices and firm performance. Accounting and Finance, 51, 517-547.

Kozlowski, S. W. J., \& Hattrup, K. (1992). A disagreement about within-group agreement: Disentangling issues of consistency versus consensus. Journal of Applied Psychology, 77, 161-167.

Kriauciunas, A., Parmigiani, A., \& Rivera-Santos, M. (2011). Leaving our comfort zone: Integrating established practices with unique adaptations to conduct survey-based strategy research in nontraditional contexts. Strategic Management Journal, 32, 994-1010.

Langton, L., \& Piquero, N. L. (2007). Can general strain theory explain white-collar crime? A preliminary investigation of the relationship between strain and select white-collar offenses. Journal of Criminal Justice, 35, 1-15.

Lawrence, B. S. (1997). The black box of organizational demography. Organization Science, 8, 1-22.

Lawshe, C. H. (1975). A quantitative approach to content validity. Personnel Psychology, 28, 563-575.

Liu, Y., Taffler, R., \& John, K. (2009). CEO value destruction in M\&A deals and beyond. Working paper, University of Edinburgh, UK.

Mackenzie, S. B., Podsakoff, P. M., \& Fetter, R. (1991). Organizational citizenship behavior and objective productivity as determinants of managerial evaluations of salespersons performance. Organizational Behavior and Human Decision Processes, 50, 123-150.

Malmendier, U., \& Tate, G. (2005). CEO overconfidence and corporate investment. Journal of Finance, 60, 2661-2700.

Malmendier, U., \& Tate, G. (2008). Who makes acquisitions? CEO overconfidence and the market's reaction. Journal of Financial Economics, 89, 20-43.
McClelland, P. L., Liang, X., \& Barker, V. L. (2010). CEO commitment to the status quo: Replication and extension using content analysis. Journal of Management, 36, 1251-1277.

McEachern, R. W. (1998). Meeting minutes as symbolic action. Journal of Business and Technical Communication, 12, 198-216.

Mehl, M. R., Gosling, S. D., \& Pennebaker, J. W. (2006). Personality in its natural habitat: Manifestations and implicit folk theories of personality in daily life. Journal of Personality and Social Psychology, 90, 862-877.

Mehl, M. R., \& Pennebaker, J. W. (2003a). The social dynamics of a cultural upheaval: Social interactions surrounding September 11, 2001. Psychological Science, 14, 579-585.

Mehl, M. R., \& Pennebaker, J. W. (2003b). The sounds of social life: A psychometric analysis of students' daily social environments and natural conversations. Journal of Personality and Social Psychology, 84, 857-870.

Menz, M. (2012). Functional top management team members: A review, synthesis, and research agenda. Journal of Management, 38, 45-80.

Mintzberg, H. (1973). Strategy-making in 3 modes. California Management Review, 16, 44-53.

Morgeson, F. P., Campion, M. A., Dipboy, R. L, Hollenbeck, J. R., Murphy, K., \& Schmitt, N. (2007). Reconsidering the use of personality tests in personnel selection contexts. Personnel Psychology, 60, 683-729.

Morris, E. (2001). Theodore Rex. New York, NY: Random House.

Mount, M. K., Barrick, M. R., \& Strauss, J. P. (1994). Validity of observer ratings of the Big 5 personality-factors. Journal of Applied Psychology, 79, 272-280.

Nadkarni, S., \& Herrmann, P. (2010). CEO personality, strategic flexibility, and firm performance: The case of the Indian business process outsourcing industry. Academy of Management Journal, 53, 1050-1073.

Nadkarni, S., \& Narayanan, V. K. (2007a). Strategic schemas, strategic flexibility and firm performance: The moderating role of industry clockspeed. Strategic Management Journal, 28, 243-270. 
Nadkarni, S., \& Narayanan, V. K. (2007b). The evolution of collective strategy frames in high- and low-velocity industries. Organization Science, 18, 688-710.

Norburn, D. (1989). The chief executive: A breed apart. Strategic Management Journal, 10, 1-15.

Oh, I. S., Wang, G., \& Mount, M. K. (2011). Validity of observer ratings of the five-factor model of personality traits: A meta-analysis. Journal of Applied Psychology, 96, 762-773.

Ones, D. S., Dilchert, S., Viswesvaran, C., \& Judge, T. A. (2007). In support of personality assessment in organizational settings. Personnel Psychology, 60, 995-1027.

Peluchette, J. V., Karl, K., \& Rust, K. (2006). Dressing to impress: Beliefs and attitudes regarding workplace attire. Journal of Business and Psychology, 21, 45-63.

Pennebaker, J. W., \& King, L. A. (1999). Linguistic styles: Language use as an individual difference. Journal of Personality and Social Psychology, 77, 1296-1312.

Pennebaker, J. W., Mehl, M. R., \& Niederhoffer, K. G. (2003). Psychological aspects of natural language use: Our words, our selves. Annual Review of Psychology, 54, 547-577.

Peterson, R. S., Smith, D. B., \& Martorana, P. V. (2006). Choosing between a rock and a hard place when data are scarce and the questions important: Reply to Hollenbeck, DeRue, and Mannor (2006). Journal of Applied Psychology, 91, 1-5.

Peterson, R. S., Smith, D. B., Martorana, P. V., \& Owens, P. D. (2003). The impact of chief executive officer personality on top management team dynamics: One mechanism by which leadership affects organizational performance. Journal of Applied Psychology, 88, 795-808.

Petit, V., \& Bollaert, H. (2012). Flying too close to the sun? Hubris among CEOs and how to prevent it. Journal of Business Ethics, 108, 265-283.

Pettigrew, A. M. (1992). On studying managerial elites. Strategic Management Journal, 13, 163-192.

Piantadosi, S., Byar, D. P., \& Green, S. B. (1988). The ecological fallacy. American Journal of Epidemiology, 127, 893-904.
Pitcher, P., Chreim, S., \& Kisfalvi, V. (2000). CEO succession research: Methodological bridges over troubled waters. Strategic Management Journal, 21, 625-648.

Priem, R., Lyon, D., \& Dess, G. (1999). Inherent limitations of demographic proxies in top management team heterogeneity research. Journal of Management, 25, 935-953.

Raskin, R., \& Shaw, R. (1988). Narcissism and the use of personal pronouns. Journal of Personality, 56, 393-404.

Robinson, W. S. (1950). Ecological correlations and the behavior of individuals. American Sociological Review, 15, 351-357.

Rovenpor, J. L. (1993). The relationship between four personal psychological constructs of chief executive officers (CEOs) and company merger and acquisition activity (MAA). Journal of Business and Psychology, 8, 27-54.

Salancik, G. R., \& Meindl, J. R. (1984). Corporate attributions as strategic illusions of management control. Administrative Science Quarterly, 29, 238-254.

Schneider, B. (1987). The people make the place. Personnel Psychology, 40, 437-453.

Schneider, B., Goldstein, H. W., \& Smith, D. B. (1995). The ASA framework: An update. Personnel Psychology, 48, 747-773.

Schriesheim, C. A., Powers, K. A., Scandura, T. A., Gardiner, C. C., \& Lankau, M. J. (1993). Improving construct measurement in management research: Comments and a quantitative approach for assessing the theoretical content adequacy of paperand-pencil survey-type instruments. Journal of Management, 19, 385-417.

Scott, B. A. (2013). A conceptual framework for the study of popularity in the workplace. Organizational Psychology Review, 3, 161-186.

Seidel, M. L., \& Westphal, J. D. (2004). Research impact: How seemingly innocuous social cues in a CEO survey can lead to change in board of director network ties. Strategic Organization, 2, 227-270.

Short, J. C., Broberg, J. C., Cogliser, C. C., \& Brigham, K. H. (2010). Construct validation using computer-aided text analysis (CATA): An 
illustration using entrepreneurial orientation. Organizational Research Methods, 13, 320-347.

Short, J. C., \& Palmer, T. B. (2008). The application of diction to content analysis research in strategic management. Organizational Research Methods, 11, 727-752.

Simonton, D. K. (1986). Presidential personality: Biographical use of the Gough Adjective Checklist. Journal of Personality and Social Psychology, 51, 149-160.

Simonton, D. K. (1988). Presidential style: Personality, biography, and performance. Journal of Personality and Social Psychology, 55, 928-936.

Stiles, P. (2001). The impact of the board on strategy: An empirical examination. Journal of Management Studies, 38, 627-650.

Stolzenberg, R. M., \& Relles, D. A. (1997). Tools for intuition about sample selection bias and its correction. American Sociological Review, 62, 494-507.

Subramaniam, M., \& Venkatraman, N. (2001). Determinants of transnational new product development capability: Testing the influence of transferring and deploying tacit overseas knowledge. Strategic Management Journal, 22, 359-378.

The National Commission for the Protection of Human Subjects of Biomedical and Behavioral Research. (1979). Belmont Report. Ethical principles and guidelines for the protection of human subjects of research. United States Department of Health \& Human Services. Retrieved from http://www.hhs.gov/ohrp/humansubjects/guidance/ belmont.html

Tourangeau, R., Rips, L. J., \& Rasinski, K. A. (2000). The psychology of survey response. Cambridge, MA: Cambridge University Press.

Trochim, W., \& Donnelly, J. P. (2006). The research methods knowledge base. Mason, $\mathrm{OH}$ : Atomic.

Vazire, S., \& Gosling, S. D. (2004). E-perceptions: Personality impressions based on personal websites. Journal of Personality and Social Psychology, 87, 123-132.

Vecchio, R. P. (2002). Leadership and gender advantage. Leadership Quarterly, 13, 643-671.

Webb, E. J., Campbell, D. T., Schwartz, R. D., \& Sechrest, L. (1966). Unobtrusive measures:
Nonreactive research in the social sciences. Chicago, IL: Rand McNally.

Webb, E. J., \& Weick, K. E. (1979). Unobtrusive measures in organizational theory: A reminder. Administrative Science Quarterly, 24, 650-659.

Westphal, J. D., \& Deephouse, D. L. (2011). Avoiding bad press: Interpersonal influence in relations between CEOs and journalists and the consequences for press reporting about firms and their leadership. Organization Science, 22, 1061-1086.

Westphal, J. D., Park, S. H., McDonald, M. L., \& Hayward, M. L. A. (2012). Helping other CEOs avoid bad press: Social exchange impression management support among CEOs in communications with journalists. Administrative Science Quarterly, 57, 217-268.

Wheeler, S., Weisburd, D., \& Bode, N. (1982). Sentencing the white collar offender: Rhetoric and reality. American Sociological Review, 47, 641-659.

Whitley, B. (2002). Principles of research in behavioral science. New York, NY: McGraw-Hill.

Williams, T. H. (1981). Huey Long. New York, NY: Vintage Books.

Winship, C., \& Mare, R. D. (1992). Models for sample selection bias. Annual Review of Sociology, 18, 327-350.

Winter, D. G. (1980). Measuring the motives of southern Africa political leaders at a distance. Political Psychology, 2, 75-85.

Winter, D. G. (1987a). Enhancement of an enemy's power motivation as a dynamic of conflict escalation. Journal of Personality and Social Psychology, 52, 41-46.

Winter, D. G. (1987b). Leader appeal, leader performance, and the motives profile of leaders and followers: A study of American presidents and elections. Journal of Personality and Social Psychology, 52, 196-202.

Winter, D. G. (1993). Power, affiliation, and war: Three tests of a motivational model. Journal of Personality and Social Psychology, 65, 532-545.

Winter, D. G. (2005). Assessing leaders' personalities: A historical survey of academic research studies. In J. M. Post (Ed.), The psychological assessment of political leaders: With profiles of 
Saddam Hussein and Bill Clinton (pp. 11-38). Ann Arbor: The University of Michigan Press.

Zahra, S. A., Priem, R. L., \& Rasheed, A. A. (2005). The antecedents and consequences of top management fraud. Journal of Management, 31, 803-828.

Zhang, Y. (2006). The presence of a separate COO/ president and its impact on strategic change and CEO dismissal. Strategic Management Journal, 27, 283-300.

Zickar, M. J., \& Carter, N. T. (2010). Reconnecting with the spirit of workplace ethnography: A historical review. Organizational Research Methods, 13, 304-319.

Zimmerman, R. D., Triana, M. C., \& Barrick, M. (2010). Predictive criterion-related validity of observer ratings of personality and job-related competencies using multiple raters and multiple performance criteria. Human Performance, 23, 361-378.

Zinko, R., Ferris, G. R., Blass, F. R., \& Laird, M. D. (2007). Toward a theory of reputation in organizations. Research in Personnel and Human Resources Management, 26, 163-204.

\section{Author biographies}

Aaron D. Hill is an Assistant Professor of Management at Oklahoma State University. His primary research interests include executives and resource orchestration. Articles that he has coauthored have appeared in journals such as Strategic Management Journal, Journal of Management, Journal of Small Business Management, and Strategic Organization.

Margaret A. White earned her $\mathrm{PhD}$ from Texas A\&M University in 1987 and is currently a professor at Oklahoma State University. Her research interests include mergers and acquisitions (M\&A) and organizational processes. Her research has appeared in Strategic Management Journal, Academy of Management Journal, Academy of Management Review, Journal of Management, Organization Studies, and Strategic Organization among others. She was Index Editor of the Academy of Management Journal and has served as a reviewer for numerous journals. She has served on the board of the Strategic Process Group of the Strategic Management Society as well as other positions of service for the profession. She is coauthor of The Management of Technology and Innovation: A Strategic Perspective with Garry Bruton. She has been an active member of the Academy of Management and Strategic Management Society for more than 20 years.

J. Craig Wallace is the William S. Spears Chair in Business Administration at Oklahoma State University. He conducts research, lectures, and consults on various organizational topics. He is primarily interested in predicting and explaining facets of performance and effectiveness by integrating individual-level theories of personality, motivation, and emotion with higher level organizational constructs such as leadership and climate. Through this research, Dr. Wallace hopes to create a work environment that is conducive to all employees, both physically and psychologically, leading to high levels of organizational effectiveness. 